\title{
Field Guide to Identify the Common Casuarina (Australian Pine) Species in Florida ${ }^{1}$
}

William S. Castle ${ }^{2}$

\section{Introduction}

There are three species of the non-native Australian pine (Casuarina spp.) in Florida. They were introduced more than 100 years ago, so they have been present long enough to be essentially naturalized. Their spread in some areas of the state has resulted in each species being classified by the Florida Department of Environmental Protection as invasive and subject to removal according to the following: "The Florida Department of Environmental Protection (FDEP) lists all "Casuarina spp.” as Class I Prohibited Aquatic Plants, which prohibits them from possession, collection, transportation, cultivation, and importation without a permit from the Department (62C-52.001 FAC). C. equisetifolia and C. glauca are listed on the Florida Department of Agriculture and Consumer Services' (DACS) Florida Noxious Weed List (5B57.004 FAC). It is unlawful to introduce, multiply, possess, move, or release Florida Noxious Weeds within the state without first obtaining a permit from the DACS.” Their presence in Florida and their impacts on native plant communities remains of concern; however, despite their ecological history, they are perceived as having particular benefits as well.

A review of the natural history the Casuarina species in Florida is available on EDIS. This guide is a companion document that provides practical information and photographs to anyone interested in field identification of these plants.

\section{Key}

Casuarina species are native to Australia, where most of the important taxonomic studies have been conducted. The following key is an edited version of a seminal work on that subject (Wilson and Johnson, 1989). It presents detailed descriptions based on Australian populations of Casuarina, but local field work indicates that the information can be used for identifications in Florida.

Casuarina (Linnaeus); from the neo-Latin casuarius (cassowary), from the resemblance of the drooping branchlets to the feathers of the cassowary

Type: C. equisetifolia Linnaeus.

Trees, dioecious, monoecious in C. equisetifolia. Young, persistent branchlets differing from deciduous branchlets in shorter articles and shape or size of leaves ('teeth'). Articles terete, smooth; furrows deep and closed, concealing stomates. Leaves in whorls of 5-20. Male inflorescences simple elongate spikes; bracteoles persistent. Female inflorescences on short lateral branchlets ('peduncles') differing in appearance from the vegetative branchlets. Cones borne among or below assimilatory branchlets, pedunculate, pubescent at least when immature; bracts thin in exposed portion, not

1. This document is HS1140, one of a series of the Horticultural Sciences Department, Florida Cooperative Extension Service, Institute of Food and Agricultural Sciences, University of Florida. Original publication date May, 2008. Visit the EDIS Web Site at http://edis.ifas.ufl.edu.

2. William S. Castle, professor, CREC-Lake Alfred, Horticultural Sciences Department, Cooperative Extension Service, Institute of Food and Agricultural Sciences, University of Florida, Gainesville, 32611.

The Institute of Food and Agricultural Sciences (IFAS) is an Equal Opportunity Institution authorized to provide research, educational information and other services only to individuals and institutions that function with non-discrimination with respect to race, creed, color, religion, age, disability, sex, sexual orientation, marital status, national origin, political opinions or affiliations. U.S. Department of Agriculture, Cooperative Extension Service, University of Florida, IFAS, Florida A. \& M. University Cooperative Extension Program, and Boards of County Commissioners Cooperating. Larry Arrington, Dean 
vertically expanded; bracteoles protruding from cone surface, never greatly thickened and always lacking a dorsal protuberance. Samara body glabrous, pale yellow-brown or greyish, dull.

A genus of 17 species in SE Asia, Malesia, Melanesia, Polynesia, New Caledonia and Australia; 6 species in Australia.

1 Phyllichnia narrow and prominently angular, occasionally flattish in older growth in C. equisetifolia but then densely pubescent on phyllichnia as well as in furrows; teeth 6-10

2 Branchlets and cones \pm densely and obviously pubescent; teeth 6-8, not

marcescent; cone body 10-24 mm long, 9-13 mm diam.; cone

bracteoles acute; samara 6-8 mm long

\section{C. equisetifolia}

2: Branchlets and cones sparsely and minutely pubescent; teeth 6-10,

marcescent or not; cone body 7-14 mm long, 4-6 mm diam.; cone

bracteoles broadly acute to acute; samara 3-4 mm long

\section{C. cunninghamiana}

1: Phyllichnia broad, flat or slightly rounded or with a median groove; teeth 8-20, mostly marcescent

3 Teeth 12-20; phyllichnia smooth, flat or slightly rounded; cone body 7-10 mm diam.; cone bracteoles 2.0-2.5 mm wide, thin, broadly acute, with no more than 1 obvious striation; samara 3.5-5.0 mm long

4 Teeth on young permanent shoots long-recurved

\section{C. glauca}

\section{Casuarina equisetifolia Linnaeus}

Monoecious tree 6-35 m high. Bark scaly, greybrown to black. New shoots with teeth erect.

Branchlets drooping, to $30 \mathrm{~cm}$ long; articles 5-13 mm long, 0.5-1.0 mm diam.; furrows usually densely pubescent; phyllichnia angular or occasionally flat in older growth, glabrous or pubescent; teeth 7 or 8 , occasionally 6, erect (rarely spreading in New Guinea), 0.3-0.8 mm long, not marcescent. Male spikes 0.7-4 cm long, 7-11.5 whorls per cm; anther 0.6-0.8 mm long. Cones sparsely pubescent to tomentose; peduncle 3-13 mm long; cone body 10-24 mm long, 9-13 mm diam.; bracteoles acute. Samara 6-8 mm long. Coast
Sheoak. There are 2 subspecies, subsp. Equisetifolia and incana.

\section{Casuarina cunninghamiana Miquel}

Tree 15-35 m high. Bark finely fissured and scaly, grey-brown. Teeth on new shoots erect. Branchlets drooping in vigorous specimens, erect in depauperate specimens; articles 4-9 mm long, 0.4-0.7 mm diam., mostly glabrous; edges of furrows often marked (when dry) by a slight ridge; phyllichnia angular to flat with a median rib; teeth 6-10, erect, 0.3-0.5 mm long, marcescent or not. Male spikes 1.2-4 cm long, 7-10 whorls per cm; anther c. $0.8 \mathrm{~mm}$ long. Cones ferruginous- to white-pubescent, becoming glabrous; peduncle 3-12 mm long; cone body 9-18 mm long, 7-9 mm diam.; bracteoles broadly acute. Samara 3.5-5.0 mm long. Swamp oak.

\section{Field Identification...looking at the tree}

Identification can begin with the appearance of the whole tree because certain features are reasonably consistent.

C. equisetifolia: Trees of this species are generally found in coastal locations from the middle of the state south to the Florida Keys as well as near the Everglades. In many of those sites, the trees were planted as windbreaks and for their shade. The trees often reach 40 to 50 feet or more in height, the canopy is relatively spreading and open, branches have relatively short needles that often have a "tufted" appearance and may be light-colored to yellowish. The bark is smooth and relatively thin with an obvious iron-red color beneath the bark surface and in the woody tissue. The female fruiting structures, or cones, are also distinctive for their large size and generally blocky (longer than wide) shape. Remember that this species is monoecious, and thus, if the plant has both male and female structures on it, then it is reasonably safe to conclude that it is C. equisetifolia. 


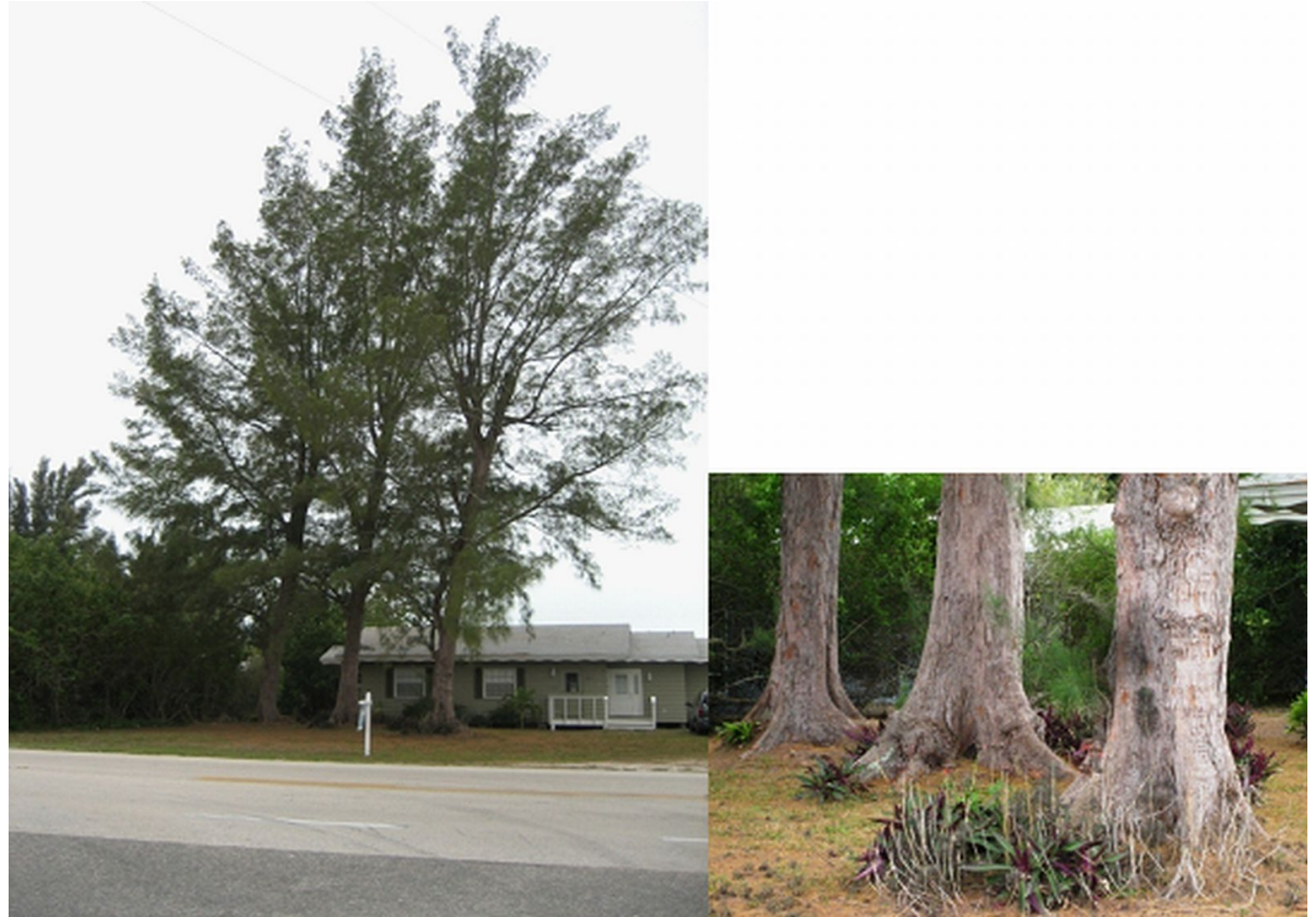

Figure 1. Mature Casuarina equisetifolia trees on Long Boat Key, Florida. Note the open, spreading canopy and the smooth bark with underlying patches of red evident in several places on the trunks.

C. cunninghamiana: Specimens of this species have been found in the Ruskin area, on Pine Island, in the Fort Pierce area, and north along the east coast, where they often occur singly or in small groups. Trees are also very tall (up to 60 feet or more) and somewhat spreading, with distinctive gray bark. The needles are intermediate in length among the three species and are usually a healthy-looking green; sometimes they also appear "tufted," like the $C$. equisetifolia trees.

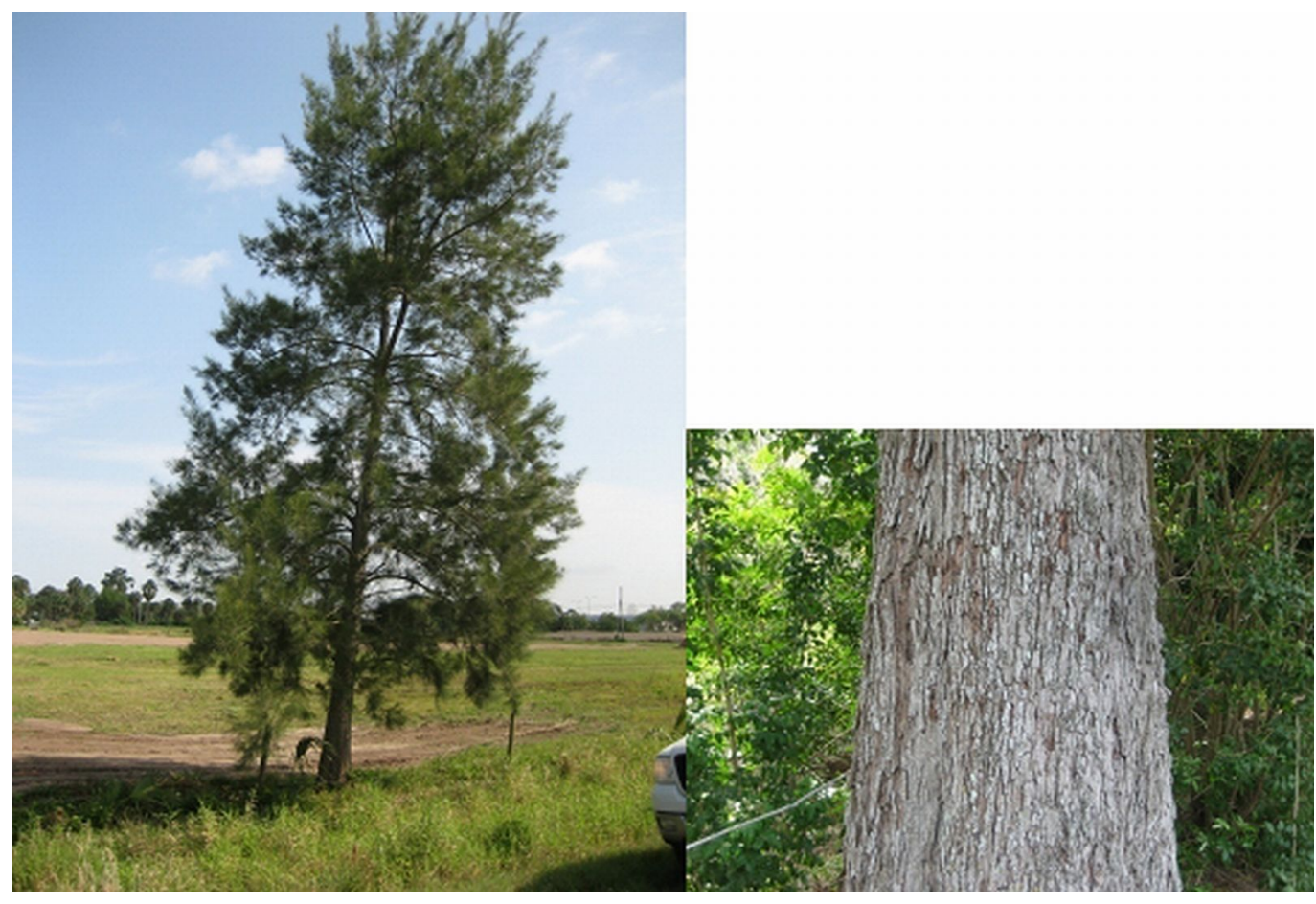

Figure 2. Casuarina cunninghamiana tree growing in Ruskin, Florida. Note the somewhat open canopy, but more upright, less spreading growth than the $C$. equisetifolia tree; also, the bark is grayer and not as smooth. 
C. glauca: Trees of this species appear to be the most widely distributed, since they are easily spotted throughout central and southern Florida in thicket-like colonies that result from their spread by root suckering. They generally seem to be shorter than trees of the other two species, but they are quite distinctive because of the dense canopy of dark green needles that can be 12 inches or longer in length and because of the presence of root suckers. Among the three species, this species could easily be judged the most attractive for its appearance. Trees with cones have not been discovered within the Florida C. glauca population.

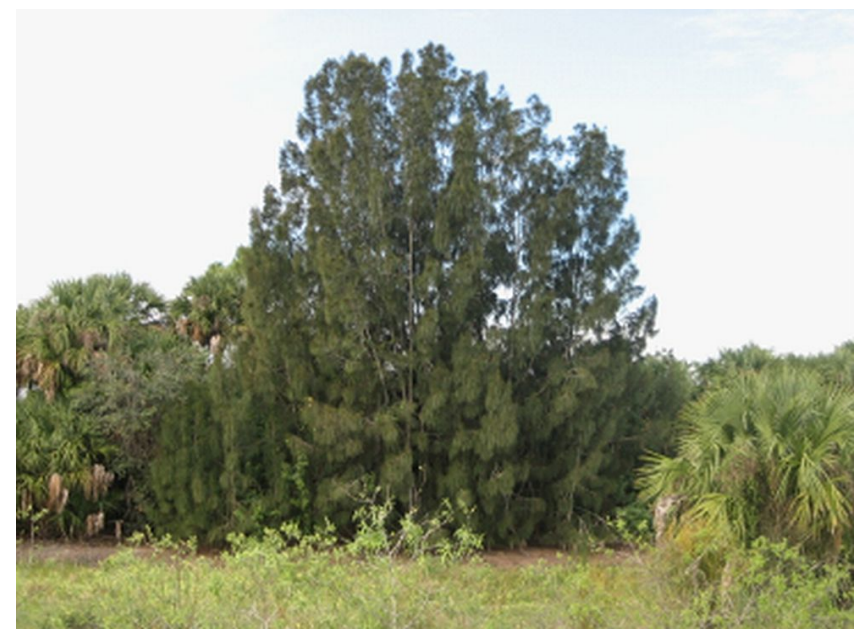

Figure 3. Cluster of Casuarina glauca trees in St. Lucie County. Note the compact nature of the canopy and the presence of taller plants in the center of the group surrounded by smaller plants, all of which probably arose vegetatively by root suckering

\section{Field Identification...looking at the needle}
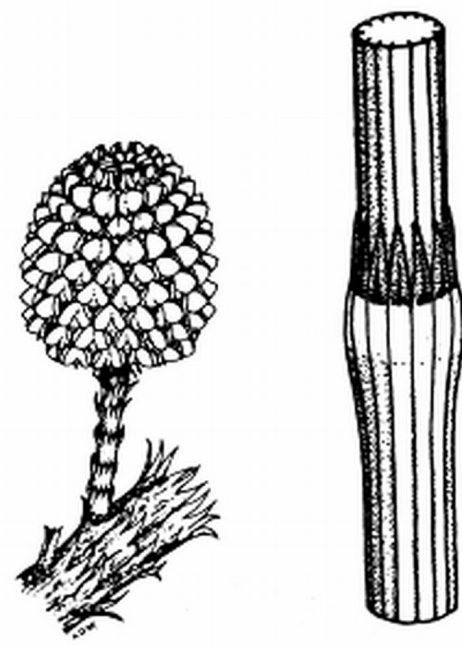

The so-called "needle" is actually a small piece of stem encased in a whorl of greatly reduced leaves the bases of which surround or clasp the stem and terminate in a point or "tooth" at the joint (node) in the stem. The node is highly visible to the naked eye.

Examination of a needle at the node with a hand lens is revealing and can be the deciding factor for species identification; however, while that is often true, some plants are confusing because of hybrid plants among the species and other factors such as the age of the needle. Those factors should be considered when making an identification. The true species become easy to identify with practice using the traits described in Table 1. Note that there are comparable descriptions based on plants in Australia or Florida. When uncertainty arises, look at several needles on one plant and sometimes needles from different parts of that plant before making an identification.

Identification using a branch needle is easiest by using an elimination process and beginning with C. glauca.

1.The $\boldsymbol{C}$. glauca tree is distinctive with its long, dark green foliage, and its nodal morphology clearly differentiates it from the other species. The key discriminating factor is the number of teeth. If there are obviously more than 10 to 12 small, stout-looking teeth that appear crowded around the stem, then it is this species. The teeth are usually light brown to gray with a distinctive transverse brown band at the base. The other species have fewer and larger teeth.
Figure 4. The diagrams illustrate the cone (left), node (middle, left), and end of a young branchlet (middle, right) of Casuarina glauca (Wilson and Johnson, 1989). The pictures are of needles collected from trees in central and eastern Florida. Note that 7 teeth are visible. 


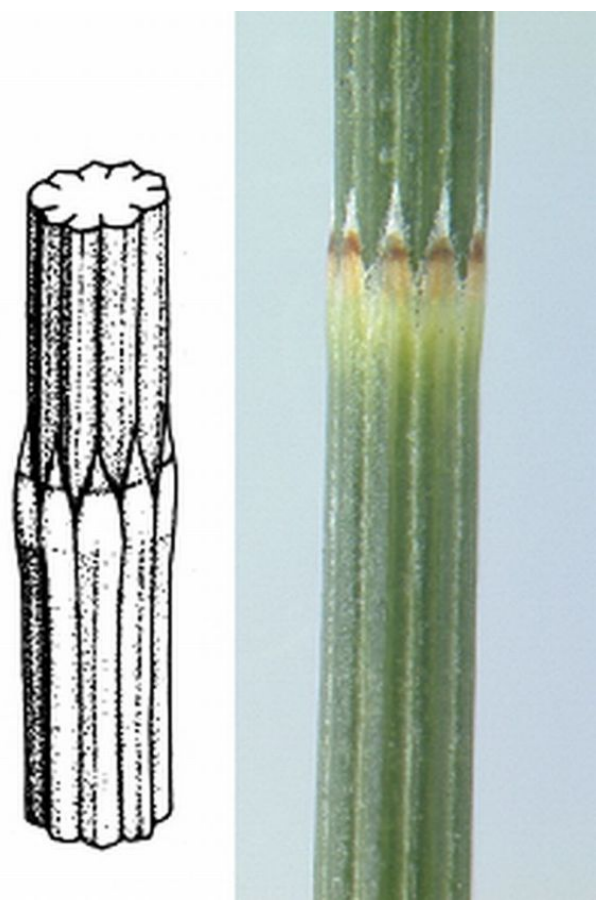

2.What easily distinguishes C. cunninghamiana are its 6 to 10 upright teeth that have light brown to gray tips with a brown transverse band about halfway between the tip of the tooth and its base.

Figure 5. Casuarina cunninghamiana. Note the four visible teeth at the node and their color and size. The tips are grayish with an obvious transverse brown band about midway along the teeth. Beneath the band, the teeth are a yellowish-green color. The diagram is from Wilson and Johnson (1989) and the pictures are of needles collected in Florida.
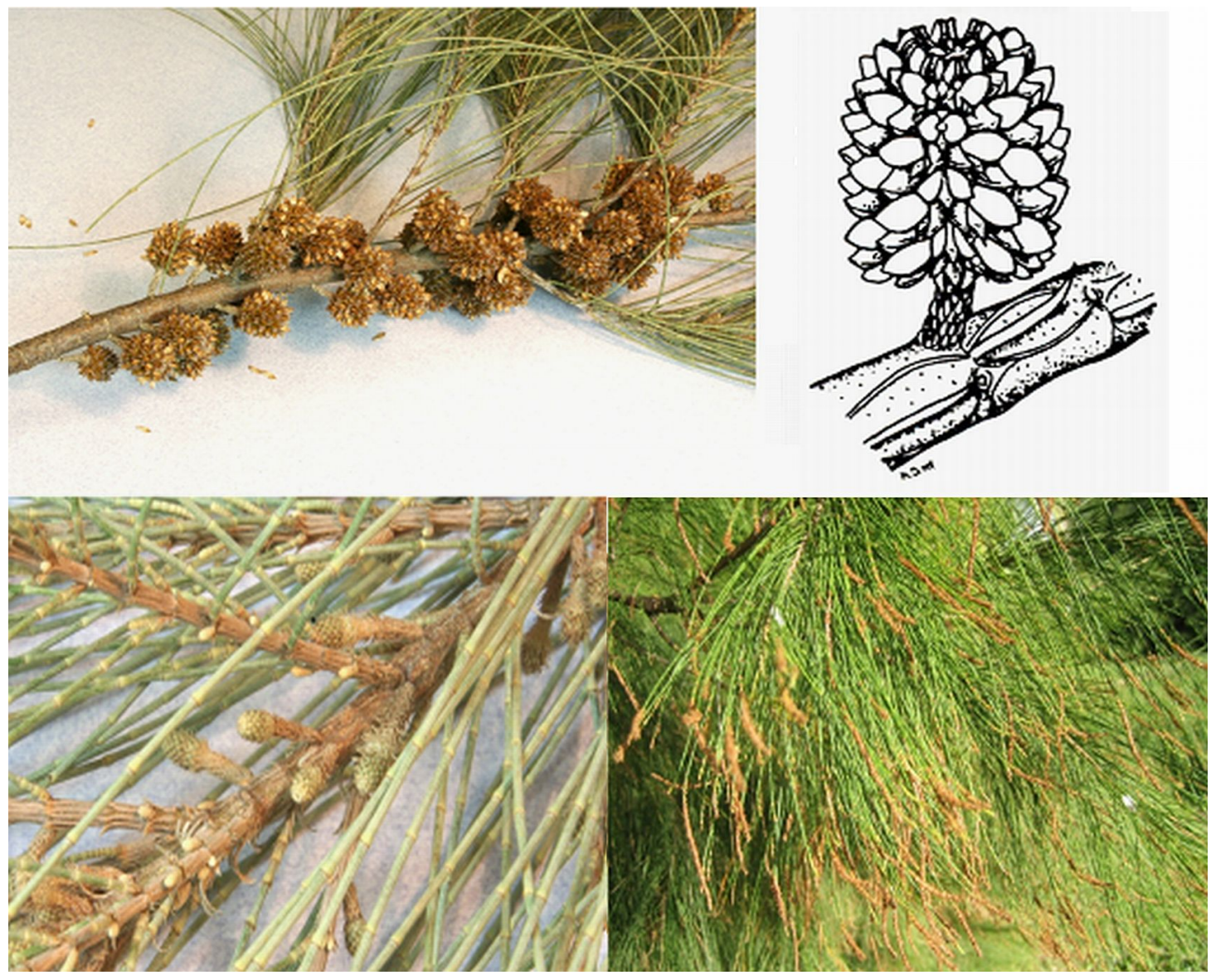

Figure 6. Casuarina cunninghamiana cones and male flowers. The cones (top left) are from a tree in Ruskin and are similar in size and shape to those shown in the diagram (Wilson and Johnson, 1989). The seeds are smaller than those collected from C. equisetifolia. The young developing cones (above, left) were produced on an old tree in Ruskin; the male flowers (above, right) were produced on a tree in Fort Pierce in late February, 2008. 


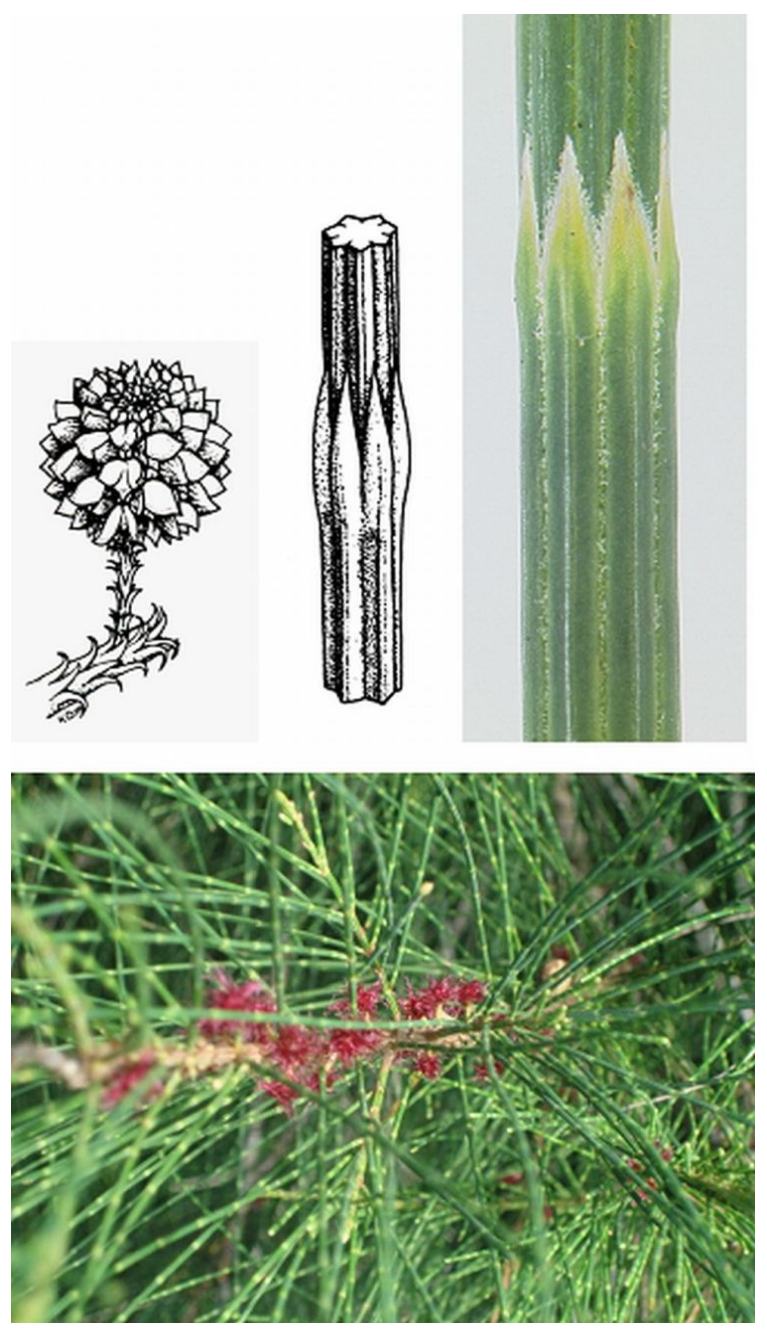

3.The easily recognized $\boldsymbol{C}$. equisetifolia features are monoecious plants, usually prolific production of large cones, and the 6 to 8 teeth that are relatively large and light green to light yellow without any transverse banding.

Figure 7. Casuarina equisetifolia female flowers, cones and nodes. Cones collected from trees in Florida that have typical traits are often larger than shown in the diagram and are blockier in shape. Note the four visible teeth, their color and size, and the overall hairiness of the needle especially at the edges of the teeth. The diagrams are from Wilson and Johnson (1989) and the pictures are of needles and cones collected in Florida.

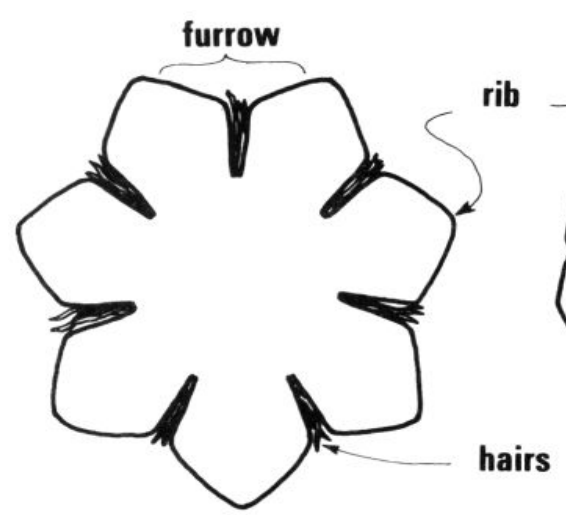

Looking at a needle with a dissecting microscope can also be helpful in examining stem cross-sections and other features.

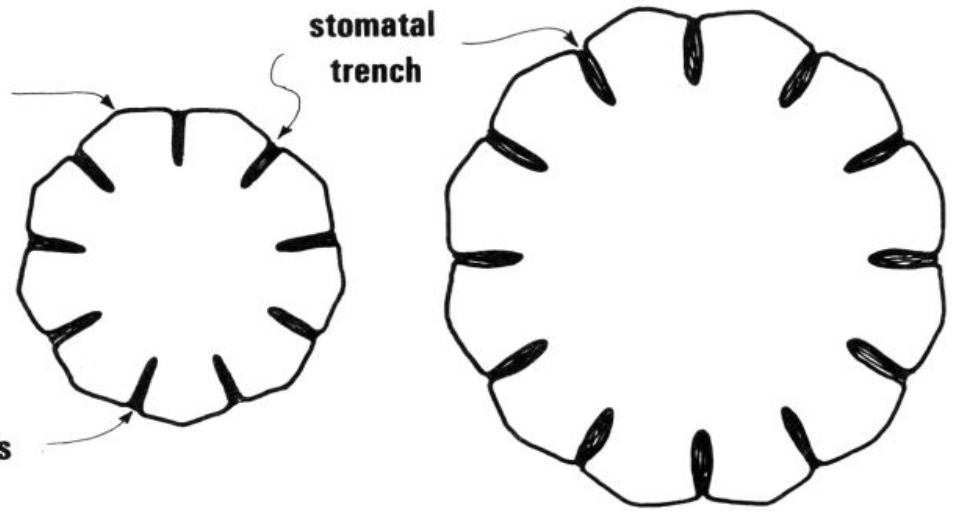

Figure 8. Casuarina stem cross-sections at the internode (Woodall and Geary, 1985). Left, C. equisetifolia has the most apparent stomatal trench with exserted hairs. Also, note the "pointy" appearance of the cross-section as compared to the rounded appearance of the other species cross-sections; middle, C. cunninghamiana has tightly packed hairs such that the stomatal trench is not obvious; and right, C. glauca also has less obvious stomatal trenches that are tightly packed with hairs. 


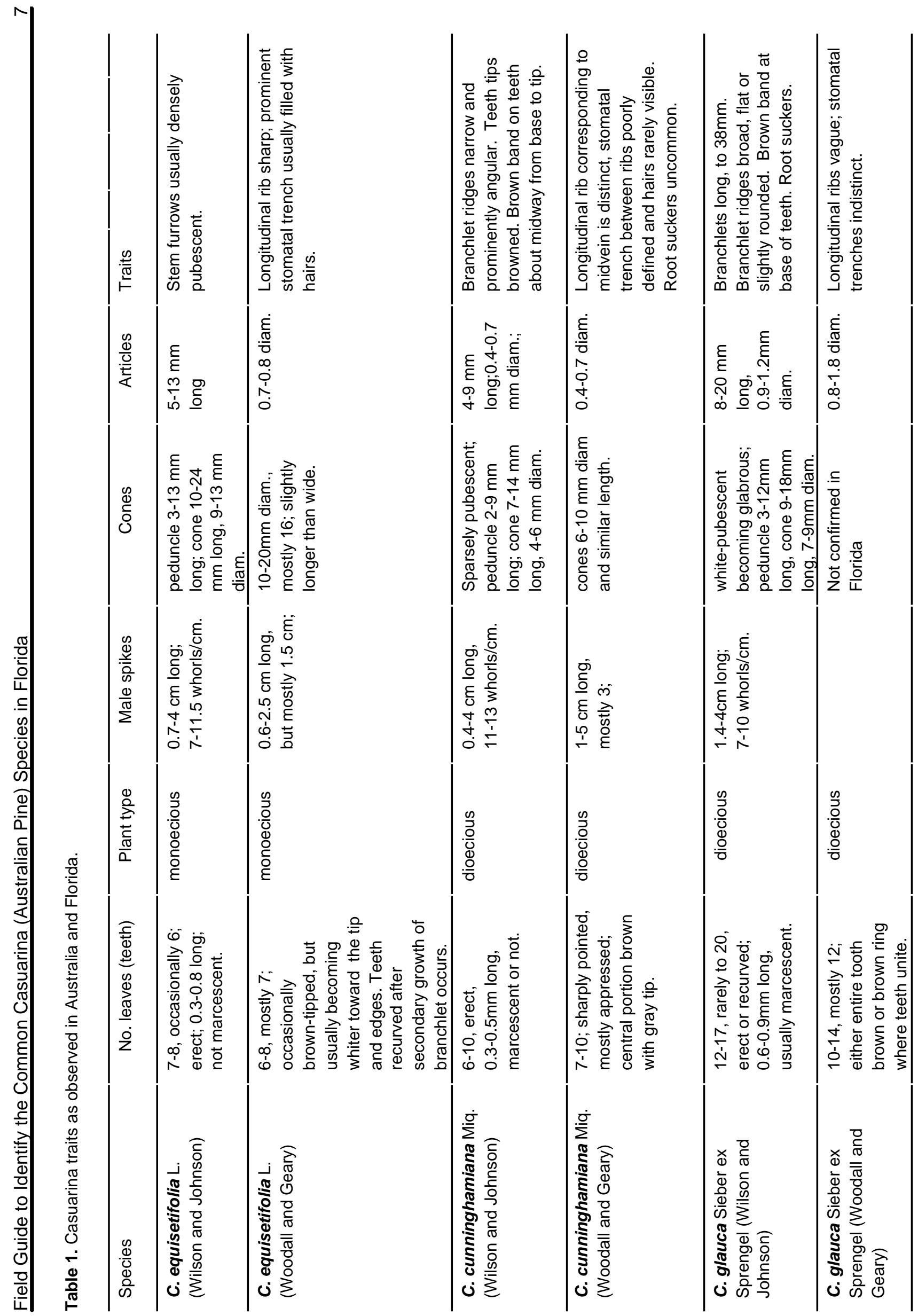




\section{Literature Cited}

Wilson, K.L. and L.A.S. Johnson. 1989.

Casuarinaceae. In: A.S. George (ed.) Flora of

Australia, vol. 3. Hamamelidales to Casuarinales.

Aus. Govt Printing Serv., Canberra.

Woodall, S.L. and T.F. Geary. 1985. Identity of Florida Casuarinas. USDA Forest Serv. SE Forest Expt. Stn. Res. Note SE-332.

\section{Glossary}

Article: A segment of a jointed stem.

Bract: Any reduced, leaf-like structure associated with a cone or flower.

Bracteole: A small leaf or leaves borne singly or two together and more or less opposite on the pedicel, cf. bract.

Deciduous: plants that drop their leaves at the end of each growing season

Dioecious: Having the male and female reproductive structures on separate plants.

Glabrous: Without hairs.

Indehiscent: a fruit that does not open when ripe to release its seeds

Marcescent: withering, but without falling off, cf. deciduous

Monoecious: Having the male and female reproductive structures on the same plant.

Peduncle: The "stalk" or small stem-like portion of an inflorescence or flowering structure; a pedicel is the comparable stalk attached to a fruit.

Phyllichnium: The ridge of a branchlet article, $\mathrm{pl}$. phyllichnia.

Pubescent: Covered with short, soft, erect hairs, cf. tomentose.

Samara: A dry, indehiscent fruit with its wall expanded into a wing or wings.
Terete: Cylindrical or nearly so, circular in cross-section

Tomentose: Covered with dense, matted, woolly hairs. 